\title{
Binding characteristics of antibodies to the TSH receptor
}

\section{Y Oda ${ }^{1}$, J Sanders, S Roberts, M Maruyama ${ }^{1}$, R Kato $^{1}, M_{\text {Perez }}{ }^{1}$, V B Petersen, N Wedlock, J Furmaniak ${ }^{1}$ and B Rees Smith ${ }^{1}$}

FIRS Laboratories, RSR Ltd, Parc Ty Glas, Llanishen, Cardiff, CF4 5DU, UK

${ }^{1}$ Department of Medicine, University of Wales College of Medicine, Heath Park, Cardiff CF4 4XN, UK

(Requests for offprints should be addressed to J Furmaniak, FIRS Laboratories, RSR Ltd, Parc Ty Glas, Llanishen, Cardiff CF4 5DU, UK)

\begin{abstract}
We have used fragments of the TSH receptor (TSHR) expressed in $E$. coli as glutathione S-transferase fusion proteins to produce rabbit polyclonal antibodies and a panel $(n=5)$ of monoclonal antibodies to the extracellular fragment of the TSHR. The binding characteristics of the antibodies to linear, conformational, glycosylated and unglycosylated forms of the receptor in different assay systems have been investigated.

The reactivity of these antibodies with the TSHR was assessed by Western blotting with both native and recombinant human TSHR expressed in CHO cells, immunoprecipitation of ${ }^{35} \mathrm{~S}$-labelled fulllength TSHR produced in an in vitro transcription/ translation system, immunoprecipitation of ${ }^{125} \mathrm{I}$ TSH/TSHR complexes, inhibition of ${ }^{125} \mathrm{I}-\mathrm{TSH}$ binding to the TSHR and fluorescence activated cell sorter (FACS) analysis of binding to $\mathrm{CHO}-\mathrm{K} 1$ cells expressing the TSHR on their cell surface. Fab fragments of monoclonal antibodies were isolated, labelled with ${ }^{125} \mathrm{I}$ and used to determine the affinity constants of these antibodies with receptor, bound and free Fab being separated by polyethylene glycol (PEG) precipitation.
\end{abstract}

Rabbit polyclonal and mouse monoclonal antibodies reacted with the TSHR in Western blotting and one monoclonal antibody (3C7) was able to inhibit ${ }^{125} \mathrm{I}$-TSH binding to native human TSHR (74\% inhibition), recombinant human TSHR (84\% inhibition) and porcine TSHR (65\% inhibition). Affinity constant values for TSHR monoclonal antibody Fab fragments calculated using Scatchard analysis were about $10^{7} \mathrm{M}^{-1}$. Four out of five monoclonal antibodies reacted in FACS analysis with TSHR expressed on the surface of CHO-K1 cells. The FACS unreactive monoclonal (3C7) bound well to detergent solubilised $\mathrm{TSH}$ receptors and this emphasised the importance of using a combination of FACS analysis and radioactivelylabelled probes in analysis of the TSH receptor.

The monoclonal antibodies produced in this study were found to be of relatively low affinity but proved useful for detection of the receptor by Western blotting and by FACS analysis.

Fournal of Molecular Endocrinology (1998) 20, 233-244

\section{INTRODUCTION}

The thyrotrophin receptor (TSHR) is a major thyroid autoantigen and TSHR autoantibodies (TRAb) are responsible for the hyperthyroidism of Graves' disease (Rees Smith et al. 1988, Furmaniak \& Rees Smith 1993). Sequence analysis indicates that the TSHR gene codes for a single peptide chain with a computed molecular mass of $84 \mathrm{kDa}$ (Libert et al. 1989, Nagayama et al. 1989, Frazier et al. 1990, Misrahi et al. 1990). However the region of the peptide chain linking the receptor's large extracellular domain to its seven membrane spanning domain is readily cleaved giving rise to an A subunit (extracellular domain) linked by a disulphide bridge(s) to a $\mathrm{B}$ subunit (membrane spanning domain) (Buckland \& Rees Smith 1984, Kajita et al. 1985a,b, Rees Smith et al. 1988, Loosfelt et al. 1992).

The binding sites for TSH and for TRAb are formed principally by the receptor's A subunit but the A subunit alone does not appear sufficient for high affinity TSH binding (Davies Jones et al. 1984, 1985). Similar observations have been reported following studies using recombinant extracellular domain of the TSHR (Harfst et al. 1992, Nagayama \& Rapoport 1992, Huang et al. 1993, Kosugi et al. 1997).

Experimentally-produced antibodies to different regions of the TSHR could be helpful in 
characterising the receptor and we now describe the preparation of polyclonal and monoclonal antibodies to the extracellular domain of the TSHR.

\section{MATERIALS AND METHODS}

\section{Production of an eukaryotic cell line expressing full length TSHR}

An ATG start codon in the $5^{\prime}$ untranslated region (5'UTR) of the full length hTSHR cDNA (Misrahi et al. 1990) was removed by AvaI digestion and the cDNA cloned into $\mathrm{pRC} / \mathrm{CMV}$ (Invitrogen, Leek, The Netherlands). DNA encoding the full length TSHR (pRC/CMV/hTSHR) was transfected into $\mathrm{CHO}$ cells (CHO-K1 from ECACC) using the calcium phosphate precipitation method (Chen \& Okayama 1987). Clones expressing TSHR were detected using ${ }^{125}$ I-TSH binding directly to cells growing on 24-well plates. The clones showing highest TSH binding were expanded and recloned twice by limiting dilution. One stable cell line expressing $4 \times 10^{5}$ TSHRs per cell, as assessed by Scatchard analysis of TSH binding (Scatchard 1949) was selected and grown in continuous culture in DMEM (Gibco-BRL, Life Technologies, Paisley, Strathclyde, UK) containing high glucose and $10 \%$ foetal calf serum (FCS), with $1000 \mu \mathrm{g} / \mathrm{ml}$ geneticin sulphate (G-418) (Life Technologies).

\section{Production of GST-TSHR fusion proteins}

Two fragments of cDNA coding for the extracellular domain of the TSHR, TSHR800 (amino acids 89-363) and TSHR400 (amino acids 245-380) were cloned into the bacterial expression vector pGEX-2T (Pharmacia, St Albans, UK) to produce in frame fusion proteins with GST (Powell et al. 1996). An overnight culture of E. coli (strain UT580) transformed with pGEX-2T/TSHR plasmids was diluted $1 / 5$ into $2 \mathrm{xYTG}$ medium (16 $\mathrm{g}$ tryptone, $10 \mathrm{~g}$ yeast extract, $5 \mathrm{~g} \mathrm{NaCl}, 20 \mathrm{~g}$ glucose per litre, $\mathrm{pH} 7 \cdot 0$ ), incubated for $3 \mathrm{~h}$ at $30{ }^{\circ} \mathrm{C}$; isopropyl- $\beta$-D-thiogalactopyranoside (IPTG) added to a final concentration of $1 \mathrm{mM}$ to induce protein expression and incubated for a further $3 \mathrm{~h}$. The bacterial pellets were resuspended in PBS $(8 \mathrm{~g}$ $\mathrm{NaCl}, \quad 0.2 \mathrm{~g} \mathrm{KCl}, \quad 1.44 \mathrm{~g} \quad \mathrm{Na}_{2} \mathrm{HPO}_{4}$ and $0.24 \mathrm{~g}$ $\mathrm{KH}_{2} \mathrm{PO}_{4}$ per litre, $\mathrm{pH} 7 \cdot 4$ ) containing $1 \%$ Triton $\mathrm{X}-100$ and sonicated three times for $1 \mathrm{~min}$ on ice. The inclusion bodies were pelleted, washed in $4 \mathrm{M}$ urea, solubilised in $8 \mathrm{M}$ urea and separated on $9 \%$ acrylamide gels (SDS-polyacrylamide gel electrophoresis; SDS-PAGE) under reducing conditions (Laemmli 1970). The glutathione S-transferase (GST) fusion proteins were electroeluted from acrylamide gel slices in $0 \cdot 1 \mathrm{M} \mathrm{NaHCO}$ and $0 \cdot 1 \%$ SDS pH 7.8 (Smith \& Corcoran 1994) dialysed against $50 \mathrm{mM}$ Tris- $\mathrm{HCl} \mathrm{pH} 8.0$ and stored in aliquots at $-70{ }^{\circ} \mathrm{C}$.

\section{Production of antibodies}

Female New Zealand White rabbits were immunised with $50 \mu \mathrm{g}$ GST-TSHR fusion proteins in complete Freund's adjuvant and boosted at 4-week intervals with $50 \mu \mathrm{g}$ GST-TSHR in incomplete Freund's adjuvant until the antibody titre was high (see below for assay method).

Six- to eight-week-old BALB/c mice were immunised with $50 \mu \mathrm{g}$ GST-TSHR fusion proteins and boosted at 3-4 week intervals until the antibody titre was high (see below for assay method). The fusion of mice spleen cells with X63-Ag8.653 myeloma cells (ECACC) was performed 4 days after the final intraperitoneal boost (De St Groth \& Scheidegger 1980). The cells were cultured in 96-well plates in DMEM with high glucose, 20\% FCS, 10\% Doma Drive (Immune Systems, Paignton, Devon, UK) and selected with HAT (Life Technologies).

Antibody secretion was detected by immunoprecipitation assays (IPA) based on ${ }^{35} \mathrm{~S}$-labelled full length TSHR produced in the in vitro transcription/ translation system (TnT) (see below for assay method). Positive wells were recloned two times by limiting dilution $(0 \cdot 5$ cells/well), grown up and used to produce ascites.

\section{Immunoprecipitation assay (IPA)}

The cDNA encoding full-length TSHR was placed downstream of the T7 promoter in pYES2 (Invitrogen) and used in an in vitro $\mathrm{Tn} T$ system (Promega, Southampton, Hants, UK) to produce TSHR labelled with ${ }^{35} \mathrm{~S}$-methionine as previously described (Colls et al. 1995, Prentice et al. 1997).

Briefly, $50 \mu \mathrm{l}{ }^{35} \mathrm{~S}$-labelled TSHR (25 00030000 c.p.m.) diluted in HSB $(150 \mathrm{mM}$ Tris $-\mathrm{HCl}$ $\mathrm{pH} 8 \cdot 3,200 \mathrm{mM} \mathrm{NaCl}$ and $10 \mathrm{mg} / \mathrm{ml}$ bovine serum albumin containing $1 \%$ Tween 20 ) were added to duplicate $50 \mu \mathrm{l}$ aliquots of diluted test sera or tissue culture supernatant and incubated for $2 \mathrm{~h}$ at room temperature. Immune complexes were then precipitated by addition of either protein A Sepharose (Sigma, Poole, Dorset, UK) or anti mouse IgG agarose (Sigma) and counted for ${ }^{35} \mathrm{~S}$.

\section{Isolation of Fab fragments}

TSHR antibody IgGs were purified from ascites fluid using affinity chromatography on Prosep A (Bioprocessing, Consett, UK) according to the manufacturer's instructions. 
Purified IgG $(10 \mathrm{mg} / \mathrm{ml})$ was dialysed against $70 \mathrm{mM}$ sodium acetate, $50 \mathrm{mM} \mathrm{NaCl} \mathrm{pH} 4 \cdot 0$ and digested for $18 \mathrm{~h}$ at $37^{\circ} \mathrm{C}$ with $1 \mathrm{mg} / \mathrm{ml}$ pepsin. The reaction mixture was dialysed against $1 \mathrm{M}$ glycine/ $\mathrm{NaOH}$ pH 8.6, $150 \mathrm{mM} \mathrm{NaCl}$ and passed through a Prosep A column in the same buffer to remove undigested $\mathrm{IgG}$ from the $(\mathrm{Fab})_{2}$.

The $(\mathrm{Fab})_{2}$ fragments were reduced with $10 \mathrm{mM}$ cysteine in $2 \mathrm{M}$ Tris $\mathrm{pH} 8.3$ for $1 \mathrm{~h}$ at $37^{\circ} \mathrm{C}$ and the reaction terminated by the addition of $200 \mathrm{mM}$ iodoacetamide in $2 \mathrm{M}$ Tris $\mathrm{pH} 8.3$ to a final concentration of $50 \mathrm{mM}$. Fab fragments were analysed by $9 \%$ SDS-PAGE and $50 \mu \mathrm{l}(20 \mu \mathrm{g})$ aliquots of $\mathrm{Fab}$ were labelled with ${ }^{125} \mathrm{I}$ using the chloramine $\mathrm{T}$ method to a specific activity of $500 \mathrm{KBq}$ per $\mu \mathrm{g}$ followed by Sephadex G-25 chromatography (Greenwood et al. 1963).

\section{Preparation of detergent solubilised native and recombinant human TSHR}

CHO-K1 cells were grown to confluence (4 days) in a $175 \mathrm{~cm}^{2}$ flask, the cells were washed with Dulbecco's PBS minus calcium and magnesium ions and scraped into $10 \mathrm{ml}$ ice-cold $50 \mathrm{mM} \mathrm{NaCl}$, $10 \mathrm{mM}$ Tris- $\mathrm{HCl} \mathrm{pH} 7 \cdot 5,1 \mathrm{mM}$ phenylmethylsulphonyl fluoride (PMSF; buffer A). The cells were pelleted at $1000 \mathrm{~g}$ for $5 \mathrm{~min}$ at $4{ }^{\circ} \mathrm{C}$, the pellet resuspended in $1 \mathrm{ml}$ buffer $\mathrm{A}$ and homogenised with a glass homogeniser on ice. The cell membranes were pelleted at $12000 \mathrm{~g}$ for $30 \mathrm{~min}$ at $4{ }^{\circ} \mathrm{C}$, resuspended in $1 \mathrm{ml}$ ice-cold buffer $\mathrm{A}$ with $1 \%$ Triton X-100 and homogenised. The solubilised TSHR preparations were centrifuged at $90000 \boldsymbol{g}$ for $2 \mathrm{~h}$ and the supernatant aliquoted and stored at $-70{ }^{\circ} \mathrm{C}$.

Native human TSHR was prepared from human thyroid tissue as previously described (Rickards et al. 1981) using 1\% Triton X-100.

\section{Precipitation of TSHR $/{ }^{125} \mathrm{I}-\mathrm{TSH}$ complexes}

Solubilised porcine TSHR (RSR Ltd, Cardiff, UK) or recombinant human TSHR were incubated for $2 \mathrm{~h}$ at room temperature with an equal volume of ${ }^{125}$ I-labelled bovine TSH (24 000 c.p.m.; RSR Ltd) to form TSHR/TSH complexes. Fifty microlitres TSHR/TSH complex were incubated with $50 \mu \mathrm{l}$ antibody for $1 \mathrm{~h}$ at $37^{\circ} \mathrm{C}$. Fifty microlitres protein A (10\% suspension; RSR Ltd) were then added and incubated for $1 \mathrm{~h}$ at room temperature. The mixture was then diluted with $1 \mathrm{ml}$ assay buffer and centrifuged $\left(1500 \mathrm{~g}\right.$ for $30 \mathrm{~min}$ at $\left.4{ }^{\circ} \mathrm{C}\right)$ and the pellet washed once with $1 \mathrm{ml}$ assay buffer and counted for ${ }^{125} \mathrm{I}$.

\section{Western blot analysis}

Twenty five microlitres solubilised CHO-K1 cells, recombinant human TSHR or native human TSHR were mixed with an equal volume of sample buffer (4\% SDS, 20\% glycerol, $100 \mathrm{mM}$ Tris- $\mathrm{HCl} \mathrm{pH} 6 \cdot 8$, $0.002 \%$ bromophenol blue) plus dithiothreitol $(10 \mathrm{mM})$ and heated to $100{ }^{\circ} \mathrm{C}$ for $3 \mathrm{~min}$, electrophoresed on 9\% SDS-PAGE gels and blotted onto nitrocellulose. Molecular mass markers (6H; Sigma) were run on each gel.

Western blotting analysis was carried out according to the method of Birk and Koepsell (1987). The membranes were blocked using $1 \mathrm{mg} / \mathrm{ml}$ polyvinylalcohol (PVA) in PBS and developed using anti-mouse or anti-rabbit horseradish peroxidase conjugate followed by enhanced chemiluminescence (ECL) reagents (Amersham International plc, Amersham, Bucks, UK). Calculation of relative mobility was carried out using the centre of each protein band as a reference point.

\section{TSH binding inhibition assays}

TSH binding inhibition assays were carried out according to the method of Southgate et al. (1984) using native human TSHR or recombinant human TSHR (expressed in CHO cells). Briefly, $50 \mu \mathrm{l}$ detergent solubilised TSHR were preincubated with $50 \mu \mathrm{l}$ sera, purified IgG or Fab fragment for $15 \mathrm{~min}$ at room temperature before the addition of $100 \mu \mathrm{l}^{125} \mathrm{I}$-TSH (30 000 c.p.m.) and incubation at $37{ }^{\circ} \mathrm{C}$ for $1 \mathrm{~h}$. TSHR $/{ }^{125} \mathrm{I}-\mathrm{TSH}$ complexes were precipitated by the addition of $2 \mathrm{ml} 16.5 \%$ polyethylene glycol (PEG) precipitator (RSR Ltd) and $25 \mu \mathrm{l}$ healthy blood donor serum, centrifuged at $1500 \mathrm{~g}$ for $30 \mathrm{~min}$ at $4{ }^{\circ} \mathrm{C}$, aspirated and the radioactivity of the pellets counted in a gamma counter.

\section{Scatchard analysis of ${ }^{125}$ I-labelled Fabs binding to detergent solubilised TSHR}

The characteristics of ${ }^{125}$ I-labelled Fabs binding to detergent solubilised recombinant human TSHR were assessed by Scatchard analysis (Scatchard 1949). Fifty microlitres solubilised TSHR were incubated with $50 \mu \mathrm{l}$ unlabelled Fab (concentrations ranging from 0.4 to $40 \mathrm{mg} / \mathrm{ml}$ ) and $100 \mu \mathrm{l}^{125} \mathrm{I}-\mathrm{Fab}$ (15 000 c.p.m.) for $1 \mathrm{~h}$ at $37^{\circ} \mathrm{C}$. Fifty microlitres healthy blood donor sera and $2 \mathrm{ml} 16.5 \%$ PEG (RSR Ltd) were added, mixed, centrifuged at $1500 \mathrm{~g}$ for $30 \mathrm{~min}$ at $4{ }^{\circ} \mathrm{C}$ and the radioactivity remaining in the pellet after aspiration counted. The concentrations of bound and free Fab were calculated, and a plot of bound against bound/free was used to calculate the affinities of the Fabs. 


\section{Fluorescence activated cell sorter (FACS) analysis}

CHO-K1 cells (untransfected or expressing the TSHR) were grown to confluence in $175 \mathrm{~cm}^{2}$ flasks in DMEM, $10 \% \mathrm{FCS}$ at $37^{\circ} \mathrm{C}$ and $5 \% \mathrm{CO}_{2}$. Flasks were washed two times with Dulbecco's PBS minus calcium and magnesium ions $(\operatorname{PBS}(-))$ then removed using a cell scraper into $10 \mathrm{ml} \operatorname{PBS}(-)$, washed two more times and resuspended using a needle and syringe. A total of $2 \times 10^{5}$ cells were blocked with $100 \mu \mathrm{l} 10 \%$ non-immunised rabbit sera in $\operatorname{PBS}(-)$ for $20 \mathrm{~min}$ at $4{ }^{\circ} \mathrm{C}$, centrifuged at $200 \mathrm{~g}$ for $5 \mathrm{~min}$ at $4{ }^{\circ} \mathrm{C}$ and incubated with $100 \mu \mathrm{IgG}$ $(100 \mathrm{mg} / \mathrm{ml})$ in $\operatorname{PBS}(-)$ with $1 \%$ BSA for $30 \mathrm{~min}$ at $4{ }^{\circ} \mathrm{C}$.

The cells were then washed three times with $\operatorname{PBS}(-)$ and incubated with $100 \mu \mathrm{l}$ second antibody; rabbit anti-mouse $\operatorname{Ig} \mathrm{F}\left(\mathrm{ab}^{\prime}\right)_{2}$ (Dako), FITC conjugated, diluted $1 / 40$ in $\operatorname{PBS}(-)$ with $1 \%$ BSA for $30 \mathrm{~min}$ at $4{ }^{\circ} \mathrm{C}$. The cells were washed three times with $\operatorname{PBS}(-)$ and fixed with $1 \%$ paraformaldehyde in $\operatorname{PBS}(-)$.

A total of 5000 cells were analysed for each sample using a Becton Dickinson FACScan System and experiments were repeated on three separate occasions.

\section{RESULTS}

\section{Reactivity of rabbit and mouse monoclonal antibodies in the IPA}

Two rabbits were immunised with each of the TSHR constructs (TSHR400 and TSHR800) and tested every month. Non-immunised rabbit sera and sera from rabbits immunised with a GST/ steroid 21-hydroxylase fusion protein $(\mathrm{GST} / 21 \mathrm{OH})$ (Chen et al. 1996) used as negative controls bound about $1-2 \%$ of ${ }^{35} \mathrm{~S}-\mathrm{TSHR}$ (full length) at $1 / 100$ dilution (Table 1). In contrast, sera from rabbits immunised with TSHR800 and TSHR400 diluted $1 / 100$ bound $42 \cdot 5$ and $15 \cdot 1 \%$ of ${ }^{35} \mathrm{~S}$-TSHR respectively after $4-12$ months of immunisation (Table 1). Five monoclonal antibodies were identified from three fusions $(3 \mathrm{~F} 3,3 \mathrm{E} 4,3 \mathrm{C} 6,5 \mathrm{D} 8$ and $3 \mathrm{C} 7)$. All five reacted in the IPA, showing binding to ${ }^{35} \mathrm{~S}-\mathrm{TSHR}$ of between 7 and $46 \%$ (Table 2).

\section{Precipitation of TSHR/TSH complexes}

Rabbit antisera were used to immunoprecipitate recombinant human and porcine TSHRs complexed with ${ }^{125}$ I-TSH (Table 3). Sera from rabbits immunised with TSHR400 and TSHR800 precipitated both human and porcine TSHR/ ${ }^{125} \mathrm{I}-\mathrm{TSH}$
TABLE 1. Binding of rabbit antibodies to ${ }^{35} \mathrm{~S}-\mathrm{TSHR}$ (full length). Sera from rabbits immunised with TSHR800 and TSHR400 were tested by IPA based on ${ }^{35} \mathrm{~S}$ TSHR (full length) produced in the TnT reaction. Results from the rabbits showing the best responses are shown in the table and are representative of at least five separate experiments carried out in duplicate. $\mathrm{GST} / 21 \mathrm{OH}=$ control rabbit sera from rabbits immunised with GST/human steroid 21-hydroxylase fusion protein

\begin{tabular}{|c|c|c|}
\hline & Dilution & $\%{ }^{35} \mathrm{~S}-\mathrm{TSHR}$ bound \\
\hline \multicolumn{3}{|l|}{ Rabbit serum } \\
\hline \multirow{2}{*}{ Non-immunised } & $1 / 10$ & $2 \cdot 6$ \\
\hline & $1 / 100$ & $1 \cdot 2$ \\
\hline \multirow[t]{2}{*}{ GST/TSHR800 } & $1 / 10$ & $57 \cdot 2$ \\
\hline & $1 / 100$ & $42 \cdot 6$ \\
\hline \multirow[t]{2}{*}{ GST/TSHR400 } & $1 / 10$ & $41 \cdot 2$ \\
\hline & $1 / 100$ & $15 \cdot 1$ \\
\hline \multirow[t]{2}{*}{$\mathrm{GST} / 21 \mathrm{OH}$} & $1 / 10$ & $1 \cdot 0$ \\
\hline & $1 / 100$ & $1 \cdot 2$ \\
\hline
\end{tabular}

complexes. Sera from rabbits immunised with TSHR400 cross reacted strongly with the porcine TSHR complexes, $30 \cdot 4 \%$ being bound at $1 / 10$ dilution, compared with sera from rabbits immunised with TSHR800 which precipitated $16 \cdot 2 \%$ at the same dilution and non-immunised rabbit sera which bound $12 \cdot 7 \%$. Sera from the TSHR 800 rabbits reacted more strongly with the human TSHR than sera from the TSHR 400 rabbits, $64 \%$ of the recombinant human TSHR complex was precipitated at 1/10 dilution with TSHR800 rabbit antiserum compared with $47 \cdot 5 \%$ at the same dilution for TSHR400 rabbit antiserum and $8 \cdot 3 \%$ for non-immunised rabbit sera (Table 3).

\section{Western blot analysis of solubilised human TSHR}

The five monoclonal antibodies $(3 \mathrm{C} 6,3 \mathrm{C} 7,3 \mathrm{~F} 3$, $3 \mathrm{E} 4$ and 5D8) reacted with detergent solubilised recombinant human TSHR on Western blot at $1 / 100$ and $1 / 1000$ dilution. Figure 1 shows the reaction of 3C7 TSHR monoclonal antibody (panels $\mathrm{A}$ and $\mathrm{B}$ ); a TSHR monoclonal antibody directed to the $\mathrm{C}$ terminus of the receptor (T3-495; TRANS$\mathrm{BIO}$, Boulogne, France) (panel $\mathrm{C}$ ) and a negative control monoclonal antibody to glutamic acid decarboxylase (GAD6; DSHB, Iowa City, IA, USA) (panel D) with solubilised CHO-K1 (untransfected) membranes (lane 1), recombinant human TSHR (lane 2) and native human TSHR (lane 3). Analysis of solubilised CHO cells expressing the full length TSHR with $3 \mathrm{C} 7$ shows two bands at $117 \pm 4 \mathrm{kDa}$ (mean \pm S.D.; $n=5)$ and $99 \pm 4 \mathrm{kDa}$ (mean \pm s.D.; $n=5)$ and a broad band with the centre at $58 \pm 2 \mathrm{kDa}$ (mean \pm s.D.; $n=5$ ). 
TABLE 2. Binding of TSHR monoclonal antibody ascites to ${ }^{35} \mathrm{~S}-\mathrm{TSHR}$ (full length). The TSHR monoclonals were made to one of two proteins designated TSHR400 and TSHR800. M1/21OH is a negative control monoclonal antibody which was made to a 21-hydroxylase/GST fusion protein produced in E. coli. Ascites dilutions were prepared in $150 \mathrm{mM}$ Tris- $\mathrm{HCl} \mathrm{pH} 8 \cdot 3,200 \mathrm{mM} \mathrm{NaCl}$ and $10 \mathrm{mg} / \mathrm{ml} \mathrm{BSA}$ containing $1 \%$ Tween 20 . Results shown are representative of at least five separate experiments carried out in duplicate

\begin{tabular}{|c|c|c|c|c|c|c|}
\hline \multicolumn{7}{|c|}{ 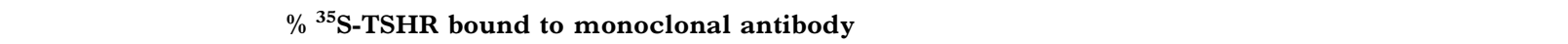 } \\
\hline & $\begin{array}{l}\text { 3F3 } \\
\text { (TSHR400) }\end{array}$ & $\begin{array}{l}\text { 3E4 } \\
\text { (TSHR400) }\end{array}$ & $\begin{array}{l}3 \mathrm{C} 6 \\
\text { (TSHR400) }\end{array}$ & $\begin{array}{l}\text { 5D8 } \\
\text { ('TSHR400) }\end{array}$ & $\begin{array}{l}\text { 3C7 } \\
\text { (TSHR800) }\end{array}$ & $\begin{array}{l}\mathrm{M} 1 / 21 \mathrm{OH} \\
(\mathrm{GST} / 21 \mathrm{OH})\end{array}$ \\
\hline \multicolumn{7}{|c|}{ Ascites dilution } \\
\hline $1 / 100$ & $15 \cdot 1$ & $18 \cdot 4$ & $46 \cdot 4$ & $13 \cdot 8$ & $25 \cdot 2$ & $3 \cdot 9$ \\
\hline $1 / 500$ & $8 \cdot 4$ & $33 \cdot 6$ & $42 \cdot 0$ & $8 \cdot 8$ & $18 \cdot 8$ & $4 \cdot 6$ \\
\hline $1 / 1000$ & $7 \cdot 1$ & $29 \cdot 8$ & $37 \cdot 1$ & $7 \cdot 9$ & $14 \cdot 7$ & $5 \cdot 8$ \\
\hline $1 / 5000$ & $6 \cdot 2$ & $18 \cdot 9$ & $22 \cdot 3$ & $6 \cdot 9$ & $7 \cdot 9$ & $5 \cdot 8$ \\
\hline $1 / 10000$ & $6 \cdot 0$ & $14 \cdot 7$ & $14 \cdot 9$ & $6 \cdot 5$ & $6 \cdot 0$ & $5 \cdot 7$ \\
\hline
\end{tabular}

TABLE 3. Immunoprecipitation of TSHR/ $/{ }^{125} \mathrm{I}-\mathrm{TSH}$ complexes by rabbit antibodies. Sera from rabbits immunised with TSHR400 and TSHR800 tested for their ability to immunoprecipitate both recombinant human (rhTSHR) and porcine TSHR (pTSHR) complexed with ${ }^{125}$ I-TSH. Results are representative of at least two separate experiments carried out in duplicate

\begin{tabular}{|c|c|c|c|}
\hline & Dilution & $\begin{array}{l}\text { rhTSHR complex } \\
\text { (\% Binding) }\end{array}$ & $\begin{array}{l}\text { pTSHR complex } \\
\text { (\% Binding) }\end{array}$ \\
\hline \multicolumn{4}{|l|}{ Rabbit serum } \\
\hline \multirow[t]{3}{*}{ Non-immunised } & $1 / 10$ & $8 \cdot 3$ & $12 \cdot 7$ \\
\hline & $1 / 50$ & $6 \cdot 8$ & $10 \cdot 1$ \\
\hline & $1 / 100$ & $7 \cdot 0$ & $10 \cdot 1$ \\
\hline \multirow[t]{3}{*}{$21 \mathrm{OH} / \mathrm{GST}$} & $1 / 10$ & $7 \cdot 8$ & $12 \cdot 0$ \\
\hline & $1 / 50$ & $8 \cdot 2$ & $11 \cdot 1$ \\
\hline & $1 / 100$ & $7 \cdot 5$ & $10 \cdot 1$ \\
\hline \multirow[t]{3}{*}{ TSHR800/GST } & $1 / 10$ & $64 \cdot 0$ & $16 \cdot 2$ \\
\hline & $1 / 50$ & $43 \cdot 5$ & $11 \cdot 3$ \\
\hline & $1 / 100$ & $30 \cdot 7$ & $10 \cdot 2$ \\
\hline \multirow{3}{*}{ TSHR400/GST } & $1 / 10$ & $47 \cdot 5$ & $30 \cdot 4$ \\
\hline & $1 / 50$ & $16 \cdot 5$ & $18 \cdot 8$ \\
\hline & $1 / 100$ & $10 \cdot 7$ & $14 \cdot 5$ \\
\hline
\end{tabular}

T3-495 antibody recognised bands of about 120 and $100 \mathrm{kDa}$ in the $\mathrm{CHO}$ cells expressing the human TSHR. In the case of native TSHR from human tissue, the 3C7 monoclonal antibody reacted with proteins at 93 and $53 \mathrm{kDa}$ whilst $\mathrm{T} 3-495$ antibody at a $1 / 1000$ dilution did not show reactivity with native human TSHR. Neither 3C7 nor T3-495 reacted with the untransfected CHO-K1 cell preparations (Fig. 1, lanes 1 in panels A-C).

Figure 2 shows the reaction of the $3 \mathrm{C} 7 \mathrm{TSHR}$ monoclonal antibody (panel B) and 3C6 monoclonal antibody (panel A) with solubilised CHO-K1 (untransfected) membranes (lane 1), recombinant human TSHR (lane 2) and native human TSHR (lane 3). The 3C6 monoclonal showed a similar reactivity to $3 \mathrm{C} 7$ (Fig. 1, panels A, B; Fig. 2, panel $\mathrm{B})$ with the two bands at $117 \pm 4 \mathrm{kDa}$ (mean \pm s.D.; $n=5)$ and $99 \pm 1.5 \mathrm{kDa}$ (mean \pm S.D.; $n=5)$ but differed from $3 \mathrm{C} 7$ in its reactivity to a broad band with the centre at $52 \pm 1 \mathrm{kDa}$ (mean \pm s.D.; $n=5$ ). 3C6 showed no reaction with the A subunit of the native TSHR extracted from human thyroid tissue.

Antisera from both TSHR400 and TSHR 800 immunised rabbits diluted $1 / 100$ and analysed by Western blotting showed a similar pattern of reactivity to recombinant human TSHR as the monoclonal antibodies (3C6 and 3C7). In particular, bands at $119 \pm 6 \mathrm{kDa}$ (mean \pm S.D.; $n=5$ ) and $102 \pm 5 \mathrm{kDa}$ (mean \pm S.D.; $n=5$ ) and a broad band with the centre at $54 \pm 1 \mathrm{kDa}($ mean \pm S.D.; $n=5)$ were recognised (data not shown).

\section{Inhibition of TSH binding to TSHR}

Only one out of the 5 TSHR monoclonal antibodies (3C7) was able to inhibit ${ }^{125}$ I-TSH binding to native human TSHR (74\% inhibition), recombinant 


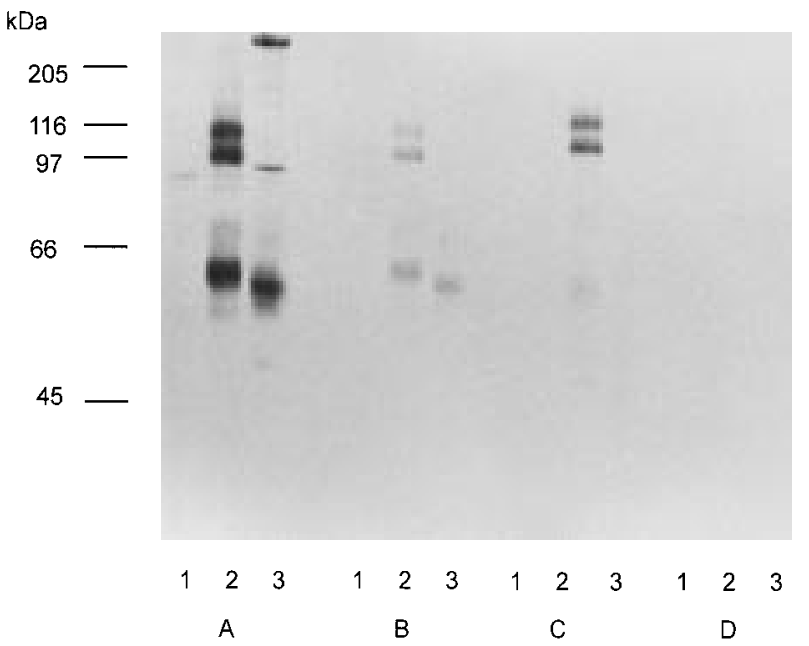

FIGURE 1. Analysis of reactivity of TSHR monoclonal antibody by Western blotting. Panel $\mathrm{A}=$ reaction with TSHR monoclonal antibody (3C7) diluted 1:100. Panel $\mathrm{B}=$ reaction with TSHR monoclonal antibody (3C7) diluted 1:1000. Panel $\mathrm{C}=$ reaction with TSHR monoclonal antibody directed to the $\mathrm{C}$-terminal part of the receptor (T3-495) diluted 1:1000. Panel $\mathrm{D}=$ reaction with monoclonal antibody to GAD6 diluted 1:100. For panels A-D: lane 1=solubilised CHO-K1 (control) membranes; lane $2=$ solubilised recombinant human TSHR (expressed in CHO-K1 cells); lane $3=$ solubilised native human TSHR. Calculation of relative mobility was carried out using the centre of each protein band as a reference point.

human TSHR (84\% inhibition) and porcine TSHR (65\% inhibition) (Fig. 3).

This inhibiting effect was studied in more detail using purified $3 \mathrm{C} 7 \mathrm{IgG}$ (Fig. 4). Concentrations of $3 \mathrm{C} 7 \mathrm{IgG}$ ranging from 0.03 to $2.5 \mathrm{mg} / \mathrm{ml}$ showed ${ }^{125} \mathrm{I}$-TSH binding inhibition ranging from 21 to $92 \%$ respectively. Furthermore, 3C7 Fab was able to inhibit TSH binding ( $41 \%$ inhibition at $0.15 \mathrm{mg} / \mathrm{ml}$; data not shown).

\section{Scatchard analysis of anti TSHR Fab fragments}

The binding characteristics of two TSHR monoclonal antibody Fabs (3C7 and 3C6) to recombinant human TSHR analysed by a Scatchard plot is shown in Fig. 5. The affinity constant $\left(K_{\mathrm{a}}\right)$ was $8.9 \times 10^{6} \mathrm{M}^{-1}$ for $3 \mathrm{C} 7$ and $1.3 \times 10^{7} \mathrm{M}^{-1}$ for $3 \mathrm{C} 6$.

\section{FACS analysis}

Four of the monoclonal antibodies $(3 \mathrm{C} 6,3 \mathrm{~F} 3,3 \mathrm{E} 4$ and 5D8) bound to recombinant human TSHR

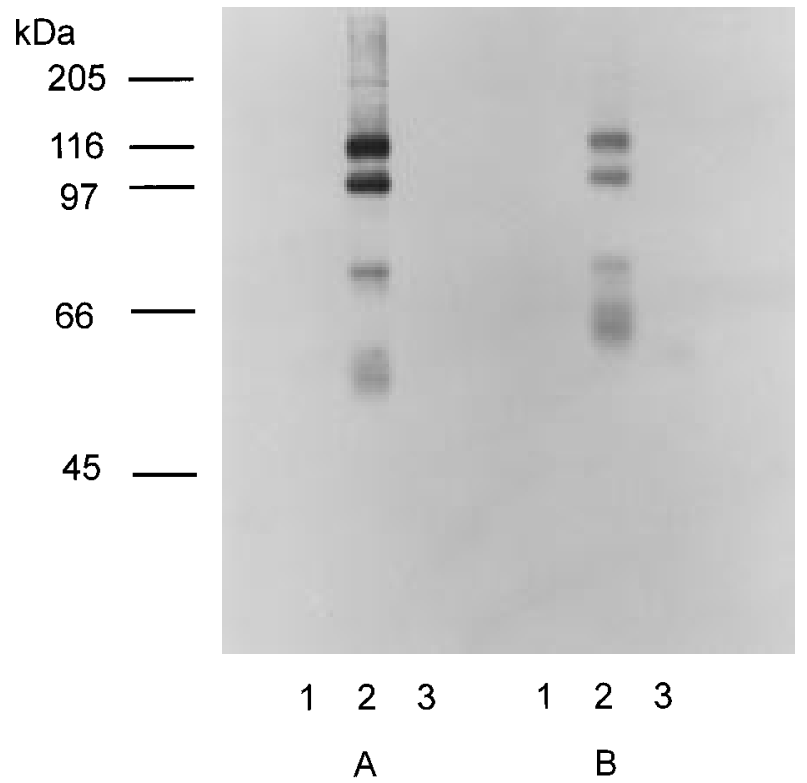

FIGURE 2. Analysis of reactivity of TSHR monoclonal antibody by Western blotting. Panel $\mathrm{A}=$ reaction with TSHR monoclonal antibody (3C6) diluted 1:1000. Panel $\mathrm{B}=$ reaction with TSHR monoclonal antibody (3C7) diluted 1:100. For panels $\mathrm{A}$ and $\mathrm{B}$ : lane $1=$ solubilised CHO-K1 (control) membranes; lane $2=$ solubilised recombinant human TSHR (expressed in CHO-K1 cells); lane $3=$ solubilised native human TSHR.

Calculation of relative mobility was carried out using the centre of each protein band as a reference point. Both monoclonals reacted with an unidentified band of $74 \mathrm{kDa}$ in the lane containing solubilised recombinant human TSHR expressed in CHO-K1 cells. This band is most probably a cleavage product of the receptor containing all or part of the extracellular domain.

expressed in CHO-K1 cells in FACS analysis, whereas $3 \mathrm{C} 7$ did not appear to recognise the receptor on the cell surface (Fig. 6, Table 4). CHO-K1 cells were used as a negative control cell line and $\mathrm{IgG}$ purified from $\mathrm{M} 1 / 21-\mathrm{OH}$ ascites (RSR Ltd) was used as negative control IgG; Table 4 shows the percentage positive cells detected. The control IgG (M1/21-OH $10 \mu \mathrm{g}$ per $\mathrm{ml}$ ) showed similar low reactivity to $\mathrm{CHO}-\mathrm{K} 1$ cells (untransfected) and $\mathrm{CHO}$ cells expressing TSHR (6.8 and $6.9 \%$ respectively). The TSHR monoclonal $3 \mathrm{C} 7 \mathrm{IgG}(10 \mu \mathrm{g}$ per $\mathrm{ml})$ also showed similar low reactivity to $\mathrm{CHO}-\mathrm{K} 1$ cells $(6 \cdot 7 \%)$ and $\mathrm{CHO}$ cells expressing TSHR (8.6\%). However, 3E4, 3C6, 5D8 and $3 \mathrm{~F} 3$ did not bind to $\mathrm{CHO}-\mathrm{K} 1$ cells $(1 \cdot 7-5 \cdot 7 \%$ cells positive) but bound well $(75 \cdot 8-83 \cdot 1 \%$ cells positive) to $\mathrm{CHO}$ cells expressing the TSHR (Fig. 6; Table 4). 

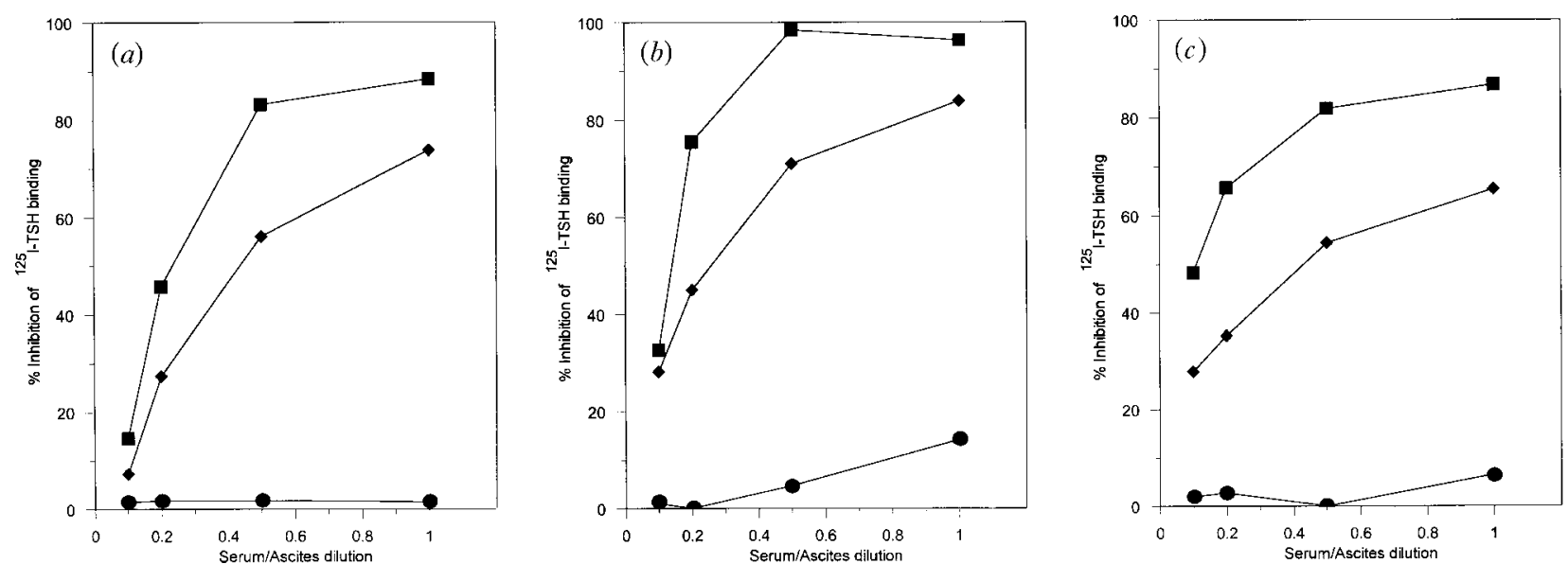

FIGURE 3. Inhibitory effect of antibodies on ${ }^{125} \mathrm{I}$-TSH binding to native human TSHR $(a)$, recombinant human TSHR $(b)$ and native porcine TSHR $(c)$. $\boldsymbol{\square}=$ TRAb in patient serum; $\bullet=3 \mathrm{C} 7 \mathrm{TSHR}$ monoclonal antibody (ascites) and $=\mathrm{GAD}_{65}$ monoclonal antibody (ascites). Results shown in the figure are representative of at least two separate experiments carried out in duplicate.

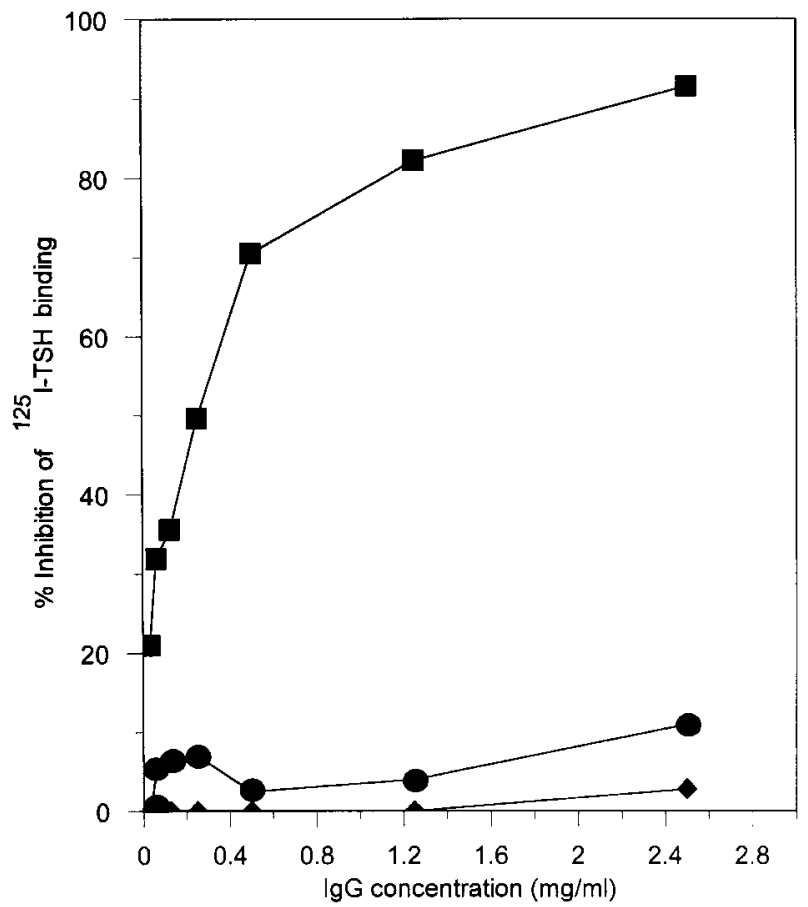

FIGURE 4. Inhibition of ${ }^{125} \mathrm{I}-\mathrm{TSH}$ binding to recombinant human TSHR by purified 3C7 TSHR IgG $(\boldsymbol{\square}), 3 \mathrm{C} 6 \mathrm{TSHR} \operatorname{IgG}(\boldsymbol{\bullet})$ and $\mathrm{M} 1 / 21 \mathrm{OH} \operatorname{IgG}(\bullet)$.

Results shown in the figure are representative of at least two separate experiments carried out in duplicate.

\section{DISCUSSION}

The TSHR is an important autoantigen in Graves' disease and the experimental production of antibodies to the receptor is critical to our understand-

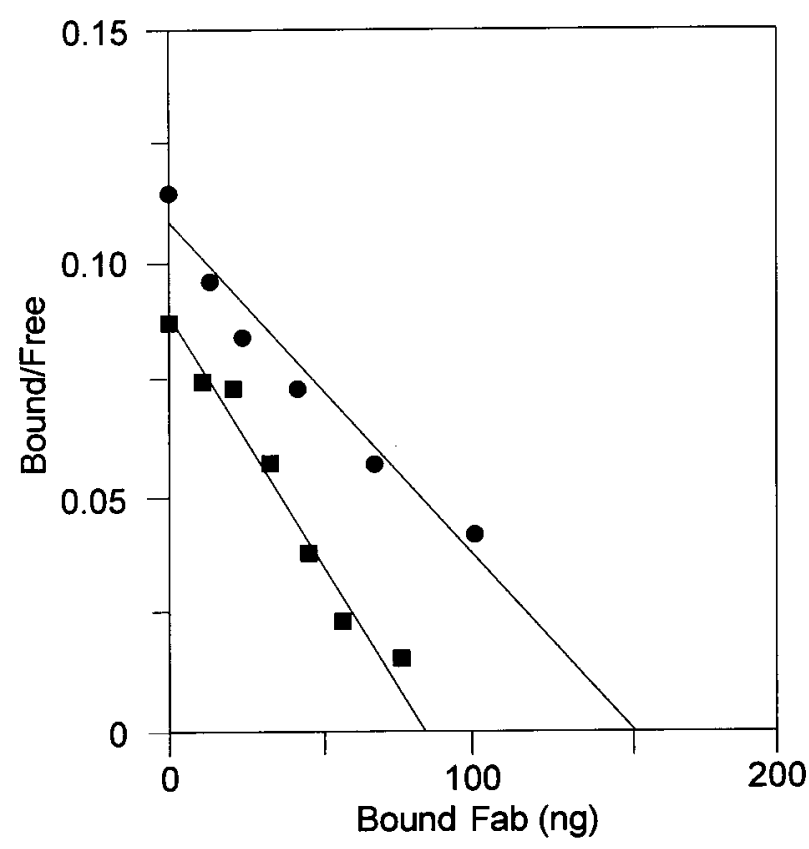

FIGURE 5. Binding of TSHR antibody Fab fragment to recombinant human TSHR expressed in CHO-K1 cells. 3C6 TSHR Fab (ם), 3C7 TSHR Fab ( $\mathbf{0})$.

ing of the receptor's structure and function and how it interacts with TSH and TRAb. However, the receptor is present in small amounts on the cell surface and has proved difficult to purify in large enough quantities to immunise experimental animals. Therefore we used two GST-TSHR fusion proteins produced in $E$. coli for immunisation and have produced rabbit polyclonal antibodies and 
CHO-K1
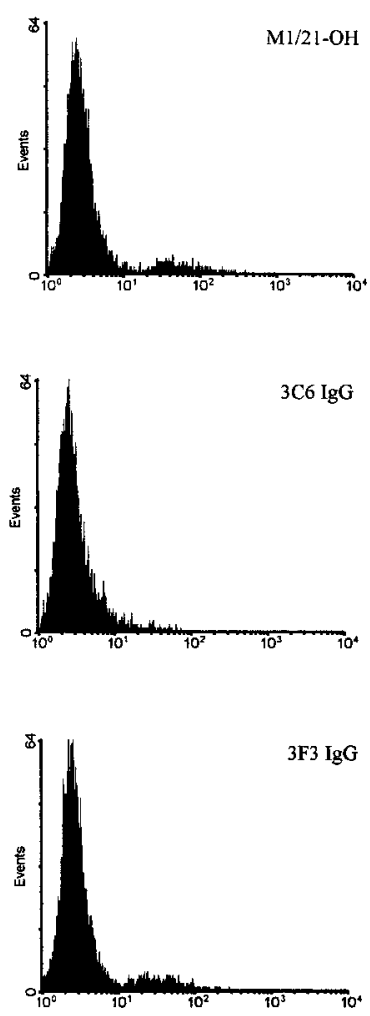

CHO-TSHR
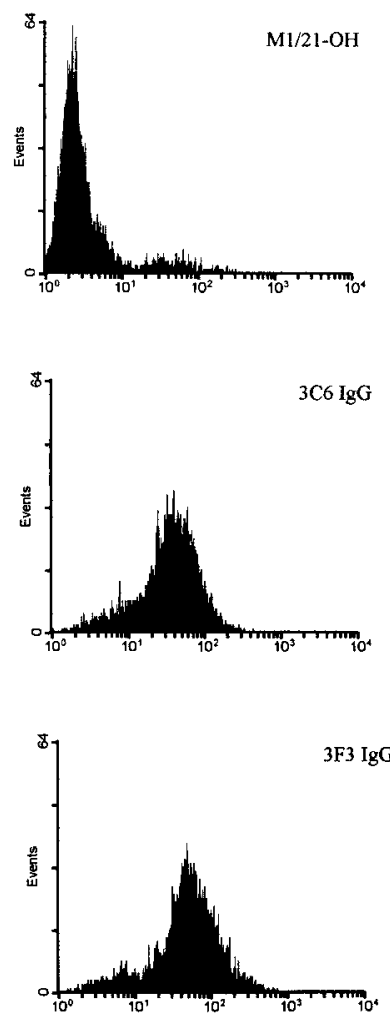

CHO-K1
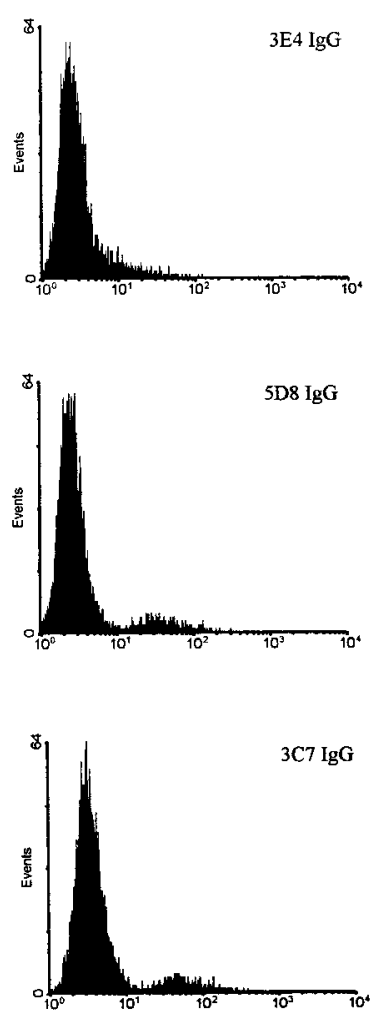

I'luorescence intensity
CHO-TSHR
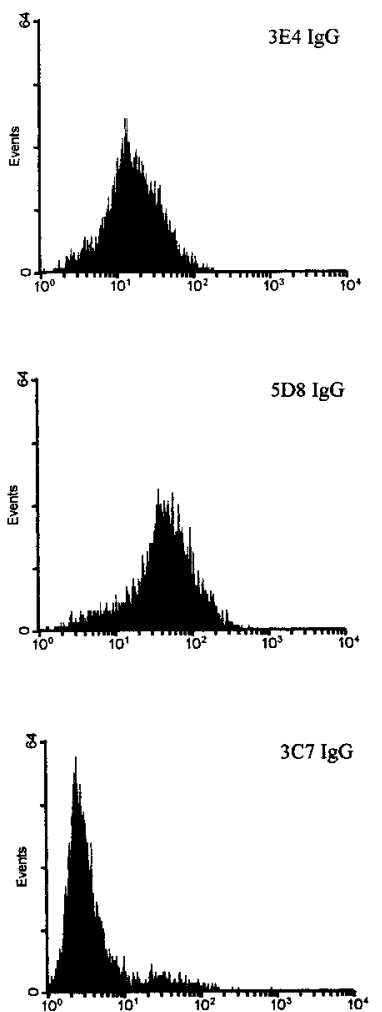

FIGURE 6. FACS analysis of monoclonal IgG binding to untransfected CHO-K1 cells (CHO-K1) or to CHO-K1 cells expressing the TSHR (CHO-TSHR). (The percentages of positive cells for this experiment are shown in Table 4.) 21-OH IgG: M1/21-OH monoclonal antibody to steroid 21-hydroxylase; 3C6, 3F3, 3E4, 5D8, 3C7: monoclonal antibodies to the TSHR.

a panel of five monoclonal antibodies to the extracellular domain of the human TSHR.

The rabbit polyclonal antibodies raised to both TSHR constructs (TSHR400 and TSHR800) reacted in an immunoprecipitation assay with full length ${ }^{35} \mathrm{~S}$-TSHR; highest titres were produced by sera from the rabbits immunised with the longer (TSHR800) fragment.

Rabbit polyclonal antibodies were able to immunoprecipitate ${ }^{125} \mathrm{I}$-TSH/TSHR complexes of both human and porcine TSHR. Sera from rabbits immunised with TSHR400 reacted strongly with the human and porcine TSHR/ ${ }^{125} \mathrm{I}-\mathrm{TSH}$ complexes compared with sera from rabbits immunised with TSHR800 which reacted only with human TSHR/ $/{ }^{125}$ I-TSH complexes. These differences in crossreactivity with human and porcine receptors suggest that the major epitopes recognised by sera from TSHR 800 rabbits are located in regions which are different between human and porcine TSHR sequences. In contrast, sera from rabbits immunised with TSHR400 recognised some epitopes that are common for both human and porcine TSHR sequences (there is an approximate $70 \%$ sequence identity at the amino acid level of the known TSHR extracellular domain sequences between different species) (Furmaniak \& Rees Smith 1993).

We were not successful in precipitating either recombinant human or porcine TSHR complexes with any of the monoclonals we produced. The reason for this is unclear but may reflect the relatively low affinities of the monoclonal antibodies. In addition, polyclonal antibodies are generally considered to be more suitable for immunoprecipitation than low affinity monoclonal antibodies (Harlow \& Lane 1988).

Western blot analysis of the TSHR with $3 \mathrm{C} 7$ showed the recombinant full length receptor to be present as two bands of 117 and $99 \mathrm{kDa}$ and a broad $58 \mathrm{kDa}$ protein band representing the receptor A subunit, whilst analysis with 3C6 showed the two full length bands at 117 and 
TABLE 4. FACS analysis of the binding of monoclonal antibody IgGs to intact cells. The percentage positive cells for each IgG with both $\mathrm{CHO}-\mathrm{K} 1$ cells and CHO-K1 cells expressing the TSHR are shown. Results are means \pm s.D. of three separate experiments

\begin{tabular}{ccc}
$\begin{array}{c}\text { CHO-K1/TSHR } \\
\text { positive cells }(\%)\end{array}$ & $\begin{array}{l}\text { CHO-K1 } \\
\text { positive }\end{array}$ \\
\cline { 1 - 1 } & & \\
\cline { 1 - 2 } $6 \cdot 9 \pm 3 \cdot 2$ & $6 \cdot 8 \pm 1 \cdot 4$ \\
$86 \cdot 7 \pm 1 \cdot 5$ & $1 \cdot 7 \pm 0 \cdot 9$ \\
$89 \cdot 1 \pm 1 \cdot 4$ & $5 \cdot 4 \pm 1 \cdot 0$ \\
$75 \cdot 8 \pm 13 \cdot 8$ & $2 \cdot 8 \pm 1 \cdot 6$ \\
$88 \cdot 6 \pm 2 \cdot 0$ & $5 \cdot 7 \pm 1 \cdot 7$ \\
$8 \cdot 6 \pm 1 \cdot 5$ & $6 \cdot 7 \pm 1 \cdot 2$ \\
\hline
\end{tabular}

$99 \mathrm{kDa}$ but the receptor's A subunit was present as a smaller broad band of $52 \mathrm{kDa}$. Since both of the antibodies recognise the receptor's extracellular domain these results suggest the presence of two possible cleavage sites in the receptor leading to the variations of the A subunit molecular mass. Similar observations regarding the presence of two cleavage sites in the TSHR have recently been reported by Chazenbalk et al. (1997).

Analysis of the sugar residues on the TSHR has suggested that the upper band $(117 \mathrm{kDa})$ of the full length TSHR represents fully glycosylated 'matured' TSHR while the lower band $(99 \mathrm{kDa})$ represents a high mannose precursor (Costagliola et al. 1994, Johnstone et al. 1994, Chazenbalk et al. 1996, Couet et al. 1996a,b, Sanders et al. 1997). In our studies of native human TSHR, a small amount of the native receptor was present as a single band at $93 \mathrm{kDa}$ whereas most of the receptor was detected by $3 \mathrm{C} 7$ at a molecular mass of $53 \mathrm{kDa}$ representing the A subunit (Kajita et al. 1985a,b, Rees Smith et al. 1988, Loosfelt et al. 1992). 3C6 did not react well with the native TSHR extracted from human thyroid tissue in Western blotting analysis and the reason for this is not clear at present. The differences in molecular mass between native and recombinant human TSHRs may be due in part at least to differences in the extent of glycosylation. The T3-495 monoclonal antibody reacted with the 117 and $99 \mathrm{kDa}$ bands of recombinant human TSHR but did not react with bands with molecular weights characteristic of the receptor's A or B subunits (at $1 / 1000$ dilution). Neither $3 \mathrm{C} 7$ (diluted 1/1000) nor T3-495 (diluted 1/1000) antibodies reacted with the full length native receptor in Western blotting; this was most probably related to the lower concentration of this form of the receptor in native receptor preparations. $3 \mathrm{C} 7$ was produced in response to immunisation with the extracellular region of the TSHR while the antibody T3-495 was produced using the $\mathrm{C}$-terminus of the receptor (Loosfelt et al 1992). Consequently, in our studies the reactivity of T3-495 with the full length receptor but not the A subunit would be expected. We were unable to detect any reactivity between T3-495 and the receptor B subunit in native or recombinant TSHR preparations but this could be due to a relatively low concentration of the $\mathrm{B}$ subunit.

Western blotting analysis showed that the recombinant receptor was present as both full length receptor and the A subunit whereas the native receptor extracted from thyroid tissue was present predominantly as the A subunit (Fig. 1). The differences in the amount of cleaved and uncleaved receptors present in recombinant and native TSHR preparations could be due to the difficulties in preventing rapid protease cleavage of the receptor in native thyroid tissue removed at operation whilst it is relatively simple to add protease inhibitors to cultured cells expressing the receptor as soon as they are harvested. Experimental evidence has suggested that the cleavage of the full length receptor in cultured $\mathrm{L}$ cells and thyroid cells may be dependant on a matrix metalloprotease (Couet et al. 1996a,b). In addition, recent studies have indicated that the extracellular domain may be cleaved in two positions giving rise to two different A subunit forms (Chazenbalk et al. 1997).

We were unable to detect inhibition of TSH binding to either human or porcine TSHRs with the rabbit polyclonal antibodies in contrast to other reports (Dallas et al. 1994, Harfst et al. 1994). Only one of our five monoclonal antibodies (3C7) was found to inhibit binding of ${ }^{125} \mathrm{I}-\mathrm{TSH}$ to recombinant human, native human and porcine TSHR preparations very effectively in the TRAb assay with a dilution profile similar to that seen for patient sera. The affinity of this antibody $(3 \mathrm{C} 7)$ was similar to that of $3 \mathrm{C} 6$ which did not inhibit TSH binding and this suggested that the differences in properties were due to differences in the epitopes recognised. Other laboratories have produced mouse monoclonals which appear to inhibit TSH binding but to a much lesser extent than 3C7 (Johnstone et al. 1994, Seetharamaiah et al. 1995, Nicholson et al. 1996). Consequently, this study and other studies show that to date, most mouse monoclonal antibodies raised to the receptor do not inhibit TSH binding (Johnstone et al. 1994, Seetharamaiah et al. 1995, Nicholson et al. 1996). Furthermore, none of the monoclonal antibodies we have produced had the ability to stimulate cAMP production in CHO-TSHR cells (Nagayama et al. 1989) (data not shown). This is consistent with other reports in the literature (Johnstone et al. 1994, Seetharamaiah et al. 1995, Nicholson et al. 1996) 
and overall current studies indicate that it is difficult to produce TSHR mouse monoclonal antibodies with thyroid stimulating activity. However, newer approaches using DNA immunisation may be successful (Costagliola 1996, Shimojo et al. 1996).

Purification of $3 \mathrm{C} 7 \mathrm{IgG}$ showed that a relatively high concentration $(2.5 \mathrm{mg} / \mathrm{ml})$ was needed to obtain over $90 \%$ inhibition of TSH binding. These results implied that the affinity of this monoclonal antibody was considerably lower than that of TSH. Consequently, we purified Fab fragments from both 3C7 and 3C6 monoclonal antibodies to investigate their binding to TSHR. The results of Scatchard analysis showed that $3 \mathrm{C} 7$ and $3 \mathrm{C} 6$ have affinities of $8.9 \times 10^{6}$ and $1.3 \times 10^{7} \mathrm{M}^{-1}$ respectively, approximately 1000 times lower than that of TSH $\left(1 \times 10^{10}\right.$ $\left.\mathrm{M}^{-1}\right)$; (data not shown). These results are consistent with the high concentrations of $3 \mathrm{C} 7 \mathrm{IgG}$ needed to inhibit TSH binding. However, our data suggest that $3 \mathrm{C} 7$ binds at or close to part of the TSH binding site either inhibiting TSH binding directly by binding to the TSH binding site or indirectly by steric hindrance and/or altering the conformation of the receptor preventing TSH binding.

Four of the five antibodies tested in the FACS analysis (3C6, 3F3, 3E4 and 5D8) bound to CHO-K1 cells expressing the human TSHR on their cell surface. Surprisingly $3 \mathrm{C} 7$, the antibody which shows inhibition of TSH binding to solubilised TSHR, did not appear to react with receptors on intact cells as judged by FACS analysis. This suggests that the epitope for $3 \mathrm{C} 7$ only becomes available after the receptors have been extracted from the cells and/or solubilised with detergent. The reason for this discrepancy is not clear at present but studies with native TSH receptors have shown that TSH binding affinity is increased markedly when the receptor is solubilised in non-ionic detergents (Brennan et al. 1980). This effect on TSH binding may be the result of subtle changes in the three dimensional structure of the receptor induced by detergent solubilisation. A similar effect of detergent solubilisation on the region of the receptor involved in $3 \mathrm{C} 7$ binding might explain the differences in $3 \mathrm{C} 7$ reactivity between cell surface and solubilised TSHR. This observation emphasises the importance of using a combination of FACS analysis and radioactively labelled probes in analysis of the receptor using experimentally produced antibodies.

Overall our studies indicate that the ${ }^{35} \mathrm{~S}$-labelled TSH receptor produced in the TnT system is very useful in screening and characterising experimentally produced antibodies to the TSH receptor. Using this screening technique we have been able to select the first mouse monoclonal antibody which competes effectively with labelled TSH binding to detergent solubilised TSH receptors.

The monoclonal antibodies produced in this study using fusion proteins expressed in $E$. coli were of relatively low affinity. However, experimentally produced antibodies with the high affinities characteristic of TSH and TRAbs are potentially the most interesting but these have not been described as yet. Successful production of such antibodies is likely to be related to the availability of highly purified, correctly folded TSHR preparations for immunisation or use of techniques such as DNA immunisation (Costagliola 1996).

\section{ACKNOWLEDGEMENTS}

$\mathrm{YO}, \mathrm{MM}, \mathrm{RK}$ and $\mathrm{MP}$ were in receipt of RSR fellowships. R K was also supported by a scholarship from the Ministry of Education, Science and Culture, Japan. Kathy Earlam provided excellent secretarial assistance.

\section{REFERENCES}

Birk HW \& Koepsell H 1987 Reaction of monoclonal antibodies with plasma membrane proteins after binding on nitrocellulose: renaturation of antigenic sites and reduction of non-specific antibody binding. Analytical Biochemistry 164 12-22.

Brennan A, Petersen VB, Petersen MM, Rees Smith B \& Hall R 1980 Time dependent stabilisation of the TSH-TSH receptor complex. FEBS Letters 111 35-38.

Buckland PR \& Rees Smith B 1984 A structural comparison of guinea pig thyroid and fat TSH receptors by photoaffinity labelling. FEBS Letters 116 109-114.

Chazenbalk GD, McLachlan SM, Nagayama Y \& Rapoport B 1996 Is receptor cleavage into two subunits necessary for thyrotropin action? Biochemical and Biophysical Research Communications 225 479-484.

Chazenbalk GD, Tanaka K, Nagayama Y, Kakinuma A, Jaume JC, McLachlan SM \& Rapoport B 1997 Evidence that the thyrotropin receptor ectodomain contains not one, but two cleavage sites. Endocrinology 138 2893-2899.

Chen C \& Okayama H 1987 High efficiency transformation of mammalian cells by plasmid DNA. Molecular and Cellular Biology 7 2745-2752.

Chen S, Sawicka J, Betterle C, Powell M, Prentice L, Volpato M, Rees Smith B \& Furmaniak J 1996 Autoantibodies to steroidogenic enzymes in autoimmune polyglandular syndrome, Addison's disease and premature ovarian failure. Fournal of Clinical Endocrinology and Metabolism $\mathbf{8 1}$ 1871-1876.

Colls J, Betterle C, Volpato M, Prentice L, Rees-Smith B \& Furmaniak J 1995 Immunoprecipitation assay for autoantibodies to steroid 21-hydroxylase in autoimmune adrenal diseases. Clinical Chemistry 41 375-380.

Costagliola S 1996 Generation of antibodies recognising the native structure of the TSH receptor by immunisation with cDNA gene constructs. Fournal of Endocrinological Investigation 191. 
Costagliola S, Alcalde L, Ruf J, Vassart G \& Ludgate M 1994 Overexpression of the extracellular domain of the thyrotrophin receptor in bacteria: production of thyrotrophin-binding inhibiting immunoglobulins. Fournal of Molecular Endocrinology 13 11-21.

Couet J, Sar S, Jolivet A, Hai M-TV, Milgrom E \& Misrahi M $1996 a$ Shedding of human thyrotropin receptor ectodomain. Fournal of Biological Chemistry 271 4545-4552.

Couet J, Bernard S, Loosfelt H, Saunier B, Milgrom E \& Misrahi M $1996 b$ Cell surface protein disulfide isomerase is in the shedding of human thyrotropin receptor ectodomain. Biochemistry 35 14800-14805.

Dallas JS, Desai RK, Cunningham SJ, Morris JC, Gattadahalli SS, Wagle N, Goldblum RM \& Prabhakar BS 1994 Thyrotropin (TSH) interacts with multiple discrete regions of the TSH receptor: polyclonal rabbit antibodies to one or more of these regions can inhibit TSH binding and function. Endocrinology 134 1437-1445.

Davies Jones E \& Rees Smith B 1984 A water-soluble fragment of the thyroid-stimulating hormone receptor which binds both thyroid-stimulating hormone and thyroid-stimulating hormone receptor antibodies. Fournal of Endocrinology 100 113-118.

Davies Jones E, Hashim FA, Kajita Y, Creagh FM, Buckland PR, Petersen VB, Howells RD \& Rees-Smith B 1985 Interaction of autoantibodies to thyrotropin receptor with a hydrophilic subunit of the thyrotropin receptor. Biochemical Fournal 228 111-117.

De St Groth SF \& Scheidegger D 1980 Production of monoclonal antibodies: strategy and tactics. Fournal of Immunological Methods 35 1-21.

Frazier A, Robbins L, Stork P, Sprengel R, Segaloff D \& Cone R 1990 Isolation of TSH and LH/hCG receptor cDNAs from human thyroid: regulation by tissue-specific splicing. Molecular Endocrinology 4 1264-1276.

Furmaniak J \& Rees Smith B 1993 Immunity to the thyroidstimulating hormone receptor. Springer Seminars in Immunopathology 14 309-321.

Greenwood FC, Hunter WM \& Glover JS 1963 The preparation of ${ }^{131}$ I-labelled human growth hormone of high specific radioactivity. Biochemical Fournal 89 114-123.

Harfst E, Johnstone AP \& Nussey SS 1992 Characterisation of the extracellular region of the human thyrotrophin receptor expressed as a recombinant protein. Fournal of Molecular Endocrinology 9 227-236.

Harfst E, Ross MS, Nussey SS \& Johnstone AP 1994 Production of antibodies to the human thyrotropin receptor and their use in characterising eukaryotically expressed functional receptor. Molecular and Cellular Endocrinology 102 $77-84$.

Harlow E \& Lane D 1988 Antibodies: A Laboratory Manual. Cold Spring Harbor: Cold Spring Harbor Laboratory.

Huang GC, Page MJ, Nicholson LB, Collison KS, McGregor AM \& Banga JP 1993 The thyrotrophin hormone receptor of Graves' disease: overexpression of the extracellular domain in insect cells using recombinant baculovirus, immunoaffinity purification and analysis of autoantibody binding. Fournal of Molecular Endocrinology 10 127-142.

Johnstone AP, Cridland JC, Da Costa CR, Harfst E \& Shepherd PS 1994 Monoclonal antibodies that recognise the native human thyrotropin receptor. Molecular and Cellular Endocrinology 105 121-129.

Kajita Y, Rickards CR, Buckland PR, Howells RD \& Rees Smith B $1985 a$ Analysis of thyrotropin receptors by photoaffinity labelling: orientation of receptor subunits in the cell membrane. Biochemical Fournal 227 $413-420$.
Kajita Y, Rickards CR, Buckland PR, Howells RD \& Rees Smith B $1985 b$ A structure for the porcine TSH receptor. FEBS Letters 181 218-222.

Kosugi S, Sugawa H \& Mori T 1997 Epitope analysis of the thyrotropin receptor. Molecular and Cellular Endocrinology 128 11-18.

Laemmli UK 1970 Cleavage of structural proteins during the assembly of the head of bacteriophage T4. Nature 227 680-684.

Libert F, Lefort A, Gerard C, Parmentier M, Perret J, Ludgate M, Dumont JE \& Vassart G 1989 Cloning, sequencing and expression of the human thyrotropin (TSH) receptor: evidence for binding of autoantibodies. Biochemical and Biophysical Research Communications 165 1250-1255.

Loosfelt H, Pichon C, Jolivet A, Misrahi M, Caillou B, Jamous M, Vannier B \& Milgrom E 1992 Two subunit structure of the human thyrotropin receptor. Proceedings of the National Academy of Sciences of the USA 89 3765-3769.

Misrahi M, Loosfelt H, Atger M, Sar S, Guiochon-Mantel A \& Milgrom E 1990 Cloning, sequencing and expression of the human TSH receptor. Biochemical and Biophysical Research Communications 166 394-403.

Nagayama Y \& Rapoport B 1992 The thyrotropin receptor 25 years after its discovery: new insight after its molecular cloning. Molecular Endocrinology 6 145-156.

Nagayama Y, Kaufman KD, Seto P \& Rapoport B 1989 Molecular cloning, sequence and functional expression of the cDNA for the human thyrotropin receptor. Biochemical and Biophysical Research Communications 165 1184-1190.

Nicholson LB, Vlase H, Graves P, Nilsson M, Molne J, Huang GC, Morgenthaler NG, Davies TF, McGregor AM \& Banga JP 1996 Monoclonal antibodies to the human TSH receptor: epitope mapping and binding to the native receptor on the basolateral plasma membrane of thyroid follicular cells. Fournal of Molecular Endocrinology 16 159-170.

Powell M, Prentice L, Asawa T, Kato R, Sawicka J, Tanaka H, Petersen V, Munkley A, Morgan S, Rees Smith B \& Furmaniak J 1996 Glutamic acid decarboxylase autoantibody assay using ${ }^{125} \mathrm{I}_{\text {-labelled recombinant }} \mathrm{GAD}_{65}$ produced in yeast. Clinica Chimica Acta 256 175-188.

Prentice L, Sanders JF, Perez M, Kato R, Sawicka J, Oda Y, Jaskolski D, Furmaniak J \& Rees-Smith B 1997 Thyrotropin (TSH) receptor autoantibodies do not appear to bind to the TSH receptor produced in an in vitro transcription/ translation system. Fournal of Clinical Endocrinology and Metabolism 82 1288-1292.

Rees Smith B, McLachlan SM \& Furmaniak J 1988 Autoantibodies to the thyrotrophin receptor. Endocrine Reviews 9 106-121.

Rickards CR, Buckland PR, Rees Smith B \& Hall R 1981 The interaction of Graves' IgG with the thyrotrophin receptor. FEBS Letters 127 17-21.

Sanders JF, Roberts S, Oda Y, Maruyama M, Furmaniak J \& Rees Smith B 1997 Analysis of carbohydrate residues on human recombinant TSH receptor. Fournal of Endocrinological Investigation 2026.

Scatchard G 1949 The attraction of proteins for small molecules and ions. Annals of the New York Academy of Sciences 51 660-672.

Seetharamaiah GS, Wagle NM, Morris JC \& Prabhakar BS 1995 Generation and characterisation of monoclonal antibodies to the human thyrotropin ( $\mathrm{TSH}$ ) receptor: antibodies can bind to discrete conformational or linear epitopes and block TSH binding. Endocrinology 136 $2817-2823$.

Shimojo N, Kohno Y, Yamaguchi KI, Kikuoka SI, Hoshioka A, Niimi H, Hirai A, Tamura Y, Saito Y, Kohn LD \& Tahara K 1996 Induction of Graves-like disease in mice by 
immunisation with fibroblasts transfected with the thyrotropin receptor and a class II molecule. Proceedings of the National Academy of Sciences of the USA 93 11074-11079.

Smith DB \& Corcoran LM 1994 Expression and purification of glutathione-S-transferase fusion proteins. Current Protocols in Molecular Biology 2 16.7·1-16.7.7.
Southgate K, Creagh FM, Teece M, Kingswood C \& Rees Smith B 1984 A receptor assay for the measurement of TSH receptor antibodies in unextracted serum. Clinical Endocrinology 20 539-543.

REVISED MANUSCRIPT RECEIVED 29 September 1997 